\title{
Corrigendum: What Is Seen Is Who You Are: Are Cues in Selfie Pictures Related to Personality Characteristics?
}

\author{
Bojan Musil ${ }^{1 *}$, Andrej Preglej ${ }^{1}$, Tadevž Ropert ${ }^{1}$, Lucia Klasinc ${ }^{1}$ and Nenad C. Babič ${ }^{1,2}$ \\ ${ }^{1}$ Department of Psychology, Faculty of Arts, University of Maribor, Maribor, Slovenia, ${ }^{2}$ Faculty of Civil Engineering, \\ Construction IT Centre, University of Maribor, Maribor, Slovenia
}

Keywords: selfie, self-presentation, social media, selfie coding, personality assessment

\section{A corrigendum on}

OPEN ACCESS

Edited and reviewed by: Piotr Sorokowski,

University of Wrockaw, Poland

${ }^{*}$ Correspondence:

Bojan Musil

bojan.musil@um.si

Specialty section:

This article was submitted to

Human-Media Interaction

a section of the journal

Frontiers in Psychology

Received: 31 January 2017 Accepted: 23 February 2017

Published: 07 March 2017

Citation:

Musil B, Preglej A, Ropert T, Klasinc L and Babič NC (2017) Corrigendum: What Is Seen Is Who You Are: Are Cues in Selfie Pictures Related to Personality Characteristics?

Front. Psychol. 8:353. doi: 10.3389/fpsyg.2017.00353
What Is Seen Is Who You Are: Are Cues in Selfie Pictures Related to Personality Characteristics?

by Musil, B., Preglej, A., Ropert, T., Klasinc, L., and Babič, N. Č. (2017). Front. Psychol. 8:82. doi: 10.3389/fpsyg.2017.00082

In the original article, there was an error. The wrong reference was cited, Hall and Pennington (2013), was cited instead of Hall (1964). A correction has been made to the Coding Section, Sub-Section Social Distance, first sentence of the fifth paragraph:

According to Hall (1964; see also Kress and van Leeuwen, 2006), we coded six social distances.

The authors apologize for this error and state that this does not change the scientific conclusions of the article in any way.

\section{REFERENCES}

Hall, E. T., (1964). Communication: theoretical and biological studies. Silent assumptions in social communication. Res. Publ. Assoc. Res. Nerv. Ment. Dis. 42, 41-55.

Conflict of Interest Statement: The authors declare that the research was conducted in the absence of any commercial or financial relationships that could be construed as a potential conflict of interest.

Copyright (C) 2017 Musil, Preglej, Ropert, Klasinc and Babič. This is an open-access article distributed under the terms of the Creative Commons Attribution License (CC BY). The use, distribution or reproduction in other forums is permitted, provided the original author $(s)$ or licensor are credited and that the original publication in this journal is cited, in accordance with accepted academic practice. No use, distribution or reproduction is permitted which does not comply with these terms. 